\title{
Forage intake and performance of heifers fed rice bran on Alexandergrass pasture
}

\author{
[Ingestão de forragem e performance de bezerros alimentados com farelo de arroz \\ integral em pasto de papuã] \\ M. Negrini ${ }^{1}$, M.G.Rocha ${ }^{2}$, L. Pötter ${ }^{2}$, P.O.Severo ${ }^{1}$, P.R. Salvador ${ }^{1 *}$, V.B. Rosa ${ }^{1}$, \\ L.G. Amaral Neto ${ }^{1}$, J.M.Vicente ${ }^{1}$
}

${ }^{1}$ Aluno de pós-graduação - Universidade Federal de Santa Maria - Santa Maria, RS ²Universidade Federal de Santa Maria - Santa Maria, RS

\begin{abstract}
The study was carried out to evaluate the forage intake and performance of beef heifers from 15 to 18 months of age, grazing on Alexandergrass (Urochloaplantaginea (Link) Hitch) fed rice bran (RB; 0, 0.5 and $1.0 \%$ body weight $(\mathrm{BW})$ ). The experiment consisted of a completely randomized design with repeated measurement arrangement. Rice bran increased the total dry matter (DM) intake, total crude protein intake and total digestible nutrients intake. Heifers that received 1.0\% BW of RB reduced forage DM intake, increasing by $18 \%$ stocking rate (SR) and by $27 \% \mathrm{BW}$ gain per area in comparison with the system exclusively on pasture. In the system in which the heifers were fed $0.5 \% \mathrm{BW}$ of RB, SR and gain per area were similar to other systems. In this feeding system, we observed average daily gain $18 \%$ higher than when heifers were exclusively on pasture and gain similar to that observed when using $1.0 \% \mathrm{BW}$ of RB. In Alexandergrass pasture it is recommended to supply $0.5 \% \mathrm{BW}$ of RB for beef heifers from 15 to 18 months of age, to promote better productive responses compared to heifers exclusively on pasture and similar to those observed when supplying $1.0 \% \mathrm{BW}$ of RB.
\end{abstract}

Keywords: substitution coefficient, rotational stocking grazing method, chromium oxide, energetic supplement, Urochloaplantaginea(Link) Hitch

\section{RESUMO}

O presente trabalho foi desenvolvido com o objetivo de avaliar o consumo de forragem e o desempenho de novilhas de corte dos 15 aos 18 meses de idade, em pastejo em papuã (Urochloaplantaginea(Link) Hitch), recebendo farelo de arroz integral (FAI) como suplemento $(0,0,5$ e 1,0\% do peso corporal (PC)). $O$ delineamento experimental foi o inteiramente ao acaso, com medidas repetidas no tempo. $O$ uso de FAI aumentou o consumo total de matéria seca (MS), o consumo total de proteína bruta e de nutrientes digestíveis totais em relação às novilhas exclusivamente em pastejo. As novilhas que receberam 1,0\% do PC de FAI reduziram o consumo de MS da forragem, aumentando em $18 \%$ a taxa de lotação (TxLot) e em 27\% o ganho de PC por hectare (GPA) em comparação com o sistema exclusivamente a pasto. No sistema em que as novilhas receberam 0,5\% do PC de FAI, a TxLot e o GPA foram similares aos demais sistemas. Nesse sistema alimentar, foi observado GDM $18 \%$ superior em relação às novilhas exclusivamente em pastejo e ganho similar ao uso de 1,0\% do PC de FAI. Em pastagem de papuãa é recomendado o uso de 0,5\% do PC de FAI para novilhas de corte dos 15 aos 18 meses de idade, por promover respostas produtivas superiores em relação às novilhas exclusivamente em pastejo e semelhantes às observadas quando fornecido 1,0\% do PC de FAI.

Palavras-chave: coeficiente de substituição, método de pastejo, óxido de cromo, suplemento energético, taxa de adição,Urochloaplantaginea(Link) Hitch

Recebido em 5 de janeiro de 2017

Aceito em 1 de fevereiro de 2018

*Autor para correspondência (corresponding author)

E-mail: salvador.pauloroberto@gmail.com 


\section{INTRODUCTION}

Alexandergrass (Urochloaplantaginea Link.) has been recommended by Lançanovaet al. (1988) as a forage due to its high dry matter production accompanied by good cattle performance. In a continuously stocked pastures, this forage provided proper nutrient intake, so beef heifers reached the body weight necessary to be mated at 18 months of age, with forage intake and performance similar to those grazing on Pearl millet (Costaet al., 2011; Souzaet al., 2012).

Different types of supplement were tested for cattle on continuously stocked Alexandergrass pasture (Oliveira Netoet al., 2013; Salvador et al., 2014). When heifers received a protein supplement, DM intake, average daily gain and body condition score were similar between heifers receiving supplement or not (Oliveira Netoet al., 2013). When oat grain was given at different supplementation frequencies, the average daily gain of heifers was similar among the tested feeding systems (Salvador et al., 2014). Studies on the use of energetic supplements for heifers grazing on Alexandergrass under rotational stocking, however, are lacking.

Among the energetic supplements, whole rice bran is a by-product obtained from the rice grain processing, and can be easily found in South Brazil, due to its significant rice production (CONAB, 2015). Rice bran is an alternative to the use of grain in animal feed, providing high level of energy through its high ether extract content, whose value may exceed $15 \%$ dry matter (Nutrient..., 2001). High levels of fat in the diet of ruminants, however, can reduce the fiber digestibility, particularly in diets with a greater proportion of tropical forage (Palmquist and Jenkins, 1980) as Alexandergrass, which has high levels of fiber in its composition.

Thus, there may be different production responses of the animals on pasture, according to interactions between the forage, the type and amount of supplement provided. The provision of supplement may interfere with total nutrient intake, depending on the replacement ratio of forage with supplement and/or addition on the total dry matter intake. These ratios are modified according to the characteristics of the forage base and supplement (Hodgson, 1990).
In this context, this study was performed to evaluate the dry matter intake and performance of beef heifers from 15 to 18 months old, on Alexandergrass, under rotational stocking fed whole rice bran at different levels $(0,0.5,1.0 \%$ body weight).

\section{MATERIAL AND METHODS}

The experiment was approved by the Ethics Committee for Animal Experimentation of Universidade Federal de Santa Maria (Protocol 3437051115). The experiment was conducted at the Federal University of Santa Maria, located in the physiographic region called Depressão Central, at coordinates $29^{\circ} 43^{\prime}$ S, $53^{\circ} 42^{\prime}$ 'W. Field evaluations were made from February $6^{\text {th }}$ to April $19^{\text {th }}, 2015$. The climate is Cfa, humid subtropical, according to Köppen. The soil is classified as Paleudalf (Sistema..., 2006) presenting the following average values: $\mathrm{pH}$ $\mathrm{H}_{2} \mathrm{O}$ : 5.1; SMP Index: 5.6; \% clay: $21.1 \mathrm{~m} \mathrm{~V}^{-1}$; $\mathrm{P}$ : 14.4mg dm ${ }^{3-1} ; \mathrm{K}^{+2}: 98 \mathrm{mg} \mathrm{dm}^{3-1}$; \%OM: $2.36 \mathrm{~m} \mathrm{~V}^{-}$ ${ }^{1}$; $\mathrm{Al}^{3+}$ saturation: $7.4 \%$; base saturation: $41.7 \%$; CEC pH7: $11.9 \mathrm{cmol} \mathrm{dm}^{3-1}$. The meteorological data for the months that comprised the experimental period were obtained from the National Institute of Meteorology (Consulta..., 2015). The total experimental area was 4.8 hectare divided in six experimental units, each further divided in four paddocks. The Alexandergrass pasture was established on December $5^{\text {th }}, 2014$, by two diskings, using the existing seed bank in the area. The fertilizer consisted of $250 \mathrm{~kg} \mathrm{ha}^{-1}$ of the formula 5-20-20 (N-P-K). Pastures were fertilized with $100 \mathrm{~kg} \mathrm{ha}^{-1}$ $\mathrm{N}$ as urea in three split applications equally distributed, always at postgrazing.

We adopted a rotational stocking grazing method with a variable number of animals, using Angus heifers with an initial age of 15 months and $282.11 \pm 22.3 \mathrm{~kg}$. Each experimental unit contained three test and a varied number of put and take animals in order to maintain post grazing sward height $(25 \pm 5 \mathrm{~cm})$. The sward height was measured at 30 points within the paddock.

The grazing method comprised successive periods of occupation (five days) and rest of the paddocks (15 days), on average. The sum of the rest period and the grazing period was characterized as a grazing cycle. The rest period 
was established considering a thermal sum of 200 degree days (Eloy et al., 2014).

Forage intake and performance were measured in heifers kept on Alexandergrass (Urochloaplantaginea (Link) Hitch) pasture in three feeding systems: exclusively on Alexandergrass; on Alexandergrass and fed 0.5 or $1.0 \%$ of body weight (BW) of rice bran (RB). The RB was mixed with $4 \%$ limestone and this mixture was offered daily at 9:30 am. The RB was composed (dry matter (DM) basis) of $89.7 \%$ $\mathrm{DM}, 14.1 \%$ crude protein (CP); $14.6 \%$ ether extract (EE); $69.3 \%$ total digestible nutrients (TDN), $27.3 \%$ neutral detergent fiber (NDF) and $76.8 \%$ in situ DM digestibility (ISDMD).

The average forage mass (FM; $\mathrm{kg} \mathrm{ha}^{-1} \mathrm{DM}$ ) was obtained by clipping the forage inside two quadrats $\left(0.250 \mathrm{~m}^{2}\right)$ at soil level from sites that represented the mean sward height, and the forage from cuts was separated manually into botanical and structural components. After collection, samples were weighed fresh and separated into leaves and stems. This materials were then dried in a forced-air oven at $55^{\circ} \mathrm{C}$ for $72 \mathrm{~h}$, and, afterwards, their leaf:stem ratio was measured.

Stocking rate (SR; $\left.\mathrm{kg} \mathrm{ha}^{-1} \mathrm{BW}\right)$ in each grazing cycle was calculated as the sum of the average weights of the test heifers and of each put-andtake animal multiplied by the number of days it remained in each paddock and divided by the number of days of the grazing cycle. The forage allowance (FA; kg DM $100 \mathrm{~kg}^{-1} \mathrm{BW}$ ) was calculated using the equation: $\mathrm{FA}=$ (initial forage mass in the paddock + final forage mass in the paddock)/2/occupation days of the paddock/instantaneous stocking rate*100. The leaf blade (LB) allowance (LBA; kg LB DM $100 \mathrm{~kg}^{-1} \mathrm{BW}$ ) was calculated using the equation: $\mathrm{LBA}=\mathrm{FA}^{*} \%$ leaf blades in forage mass.

To estimate the dry matter intake, we used powdered chromium oxide $\left(\mathrm{Cr}_{2} \mathrm{O}_{3}\right)$, in capsules, as an indicator of fecal output in the second $(02 / 22-03 / 10)$ and in the last grazing cycle (03/26-04/19). Two heifers per paddock were dosed with $10.0 \mathrm{~g}$ chromium oxide $\left(\mathrm{Cr}_{2} \mathrm{O}_{3}\right)$, on a daily dose at $9 \mathrm{am}$. The dosing period was twelve days, and from the eighth day onwards, feces were collected at every three hours according Kozloskiet al. (2006). Chromium levels in dried feces were determined by atomic absorption spectrophotometry (Kozloskiet al., 1998). To estimate the fecal output (FO), it was used the formula: $\mathrm{FO}=$ administered chrome ( $\mathrm{g}$ day $^{-}$ $\left.{ }^{1}\right) /$ chromium in feces $\left(\mathrm{g} \mathrm{kg}^{-1} \mathrm{DM}\right)$ (Pond et al., 1989). The total dry matter intake (FIf; kg DM day $^{-1}$ ) was evaluated by the formula: FIf $=$ FO/ $(1-$ digestibility). From these data, we calculated the forage intake, total dry matter intake, crude protein intake, neutral detergent fiber intake and total digestible nutrient intake, expressed in $\% \mathrm{BW}$. The coefficient of substitution (reduction in forage DM intake per $\mathrm{kg}$ DM of supplement consumed) and the addition rate (increase in total DM intake per kg DM of supplement consumed) were estimated according to Hodgson (1990).

Grazing simulation was made according as proposed by Euclideset al. (1992). Forage samples were oven-dried at $55^{\circ} \mathrm{C}$ for 72 hours and ground in a Wiley mill for later laboratory analysis. The dry matter content of the samples was determined by drying in an oven at $105^{\circ} \mathrm{C}$ for at least eight hours. The ash content was determined by combustion at $600^{\circ} \mathrm{C}$ for four hours and the organic matter content was obtained by mass difference. The protocols followed in laboratory analyses were: Kjeldahl method (Official... 1997) for the determination of total nitrogen; Sengeret al. (2008) for analysis of neutral detergent fiber; Demarquillyet al. (1969) for the in situ dry matter digestibility of forage and supplement; Bligh and Dyer (1959) to determine the ether extract content of the rice bran; Kunkle and Bates (1998) to calculate the TDN.

Heifers were weighed at the beginning and end of pasture grazing utilization, after solid and liquid fasting for 12 hours. Animals were also weighed at the end of each grazing cycle for subsequent calculation of stocking rate by cycle. In the same occasions of weighing, subjective evaluation of body condition score (BCS) was made, considering the condition score from 1 (very thin) to 5 (very fat) according to Lowman et al. (1973). On that occasion, hip height measurements were taken in test heifers with the aid of a ruler graduated in centimeters, for further calculation of hip height gain (HHG).

The average daily gain (ADG; kg BW day ${ }^{-1}$ ) was obtained by weight difference of test heifers between the initial and final weight divided by the number of days of evaluation. The body 
weight gain per area (BWA; kg BW ha ${ }^{-1}$ ) was obtained by dividing the average stocking rate by the average weight of test heifers in each paddock. This value was multiplied by the average gain of test heifers of the paddock and by the number of days of pasture utilization.

The experiment consisted of three feeding systems ( $0,0.5$ and $1.0 \% \mathrm{BW}$ of $\mathrm{RB})$ in a completely randomized design with repeated measures on time. For pasture variables, two replicates were used. For intake evaluation, four replicates (animals) were used in each feeding system. The variables collected only at the beginning and end of the experiment were evaluated following the structure of a completely randomized design with three feeding systems and six replications (animals). To compare treatments, variables with normality of residuals were subjected to analysis of variance by the MIXED procedure of SAS 9.4 (Statistical..., 2009). Structure selection test was performed with Bayesian Information Criterion (BIC) to determine the model which would best represent data. When difference between means was detected they were compared using lsmeansoption. The interaction between feeding systems and grazing cycles was broken down when significant at 5\%. The variables were subjected to Pearson correlation analysis. The variables leaf: stem ratio and leaf blade allowance did not show normality of residuals and were transformed by the sum of squares (SQRT(Y)).

\section{RESULTS AND DISCUSSION}

The average monthly temperature and cumulative rainfall were $24.1^{\circ} \mathrm{C}$ and $845.9 \mathrm{~mm}$, respectively, during the months that comprised the experimental period. The average monthly temperature was similar to the historical average $\left(22.5^{\circ} \mathrm{C}\right)$ and the cumulative rainfall was $161 \mathrm{~mm}$ higher than the historical rainfall $(684.7 \mathrm{~mm})$, providing suitable climatic conditions for the development of plants. The post-grazing sward height $(23.8 \mathrm{~cm})$ in the paddocks was similar $(\mathrm{P}=0.7200)$ for different feeding systems (Table 1). This value is in accordance with the experimental protocol.

There was no interaction $(\mathrm{P}>0.05)$ between feeding systems $\times$ grazing cycle for forage mass, leaf blades and stems mass, leaf: stem ratio, forage allowance and leaf blade allowance (Table 1).

Table 1. Sward characteristics and nutritive value of forage as grazed by heifers on different feeding systems

\begin{tabular}{|c|c|c|c|c|c|c|}
\hline \multirow{2}{*}{ Variables } & \multicolumn{3}{|c|}{ Feeding systems $^{1}$} & \multirow{2}{*}{$\mathrm{P}^{*}$} & \multirow{2}{*}{$\mathrm{P} * *$} & \multirow{2}{*}{$\mathrm{SD} * * *$} \\
\hline & Alexandergrass & $\mathrm{Al}+0.5$ & $\mathrm{Al}+1.0$ & & & \\
\hline Post-grazing sward height $^{2}$ & 23.7 & 24.1 & 23.5 & 0.7200 & 0.9665 & 3.0 \\
\hline Average forage mass ${ }^{3}$ & 3985.2 & 3691.9 & 3974.9 & 0.4952 & 0.9476 & 803.9 \\
\hline Leaf blade mass ${ }^{3}$ & 855.9 & 851.7 & 976.3 & 0.1019 & 0.7291 & 196.8 \\
\hline Stem mass ${ }^{3}$ & 2009.6 & 1936.8 & 2042.2 & 0.8703 & 0.9935 & 505.0 \\
\hline Leaf:stem ratio & 0.5 & 0.5 & 0.5 & 0.7129 & 0.7608 & 0.09 \\
\hline Forage allowance ${ }^{4}$ & 9.2 & 7.8 & 7.8 & 0.1946 & 0.9623 & 1.94 \\
\hline Leaf blade allowance ${ }^{4}$ & 2.1 & 1.9 & 2.0 & 0.6300 & 0.9859 & 0.36 \\
\hline In situDMdigestibility ${ }^{5}$ & 65.6 & 67.1 & 66.5 & 0.7272 & 0.1629 & 5.9 \\
\hline Neutral fiber detergent ${ }^{5}$ & $63.2^{\mathrm{a}}$ & $62.5^{\mathrm{ab}}$ & $60.0^{\mathrm{b}}$ & 0.0478 & 0.6254 & 2.78 \\
\hline Crude protein ${ }^{5}$ & $12.4^{\mathrm{b}}$ & $12.4^{\mathrm{b}}$ & $13.6^{\mathrm{a}}$ & 0.0934 & 0.9089 & 6.33 \\
\hline Total digestible nutrients ${ }^{5}$ & 62.2 & 62.6 & 62.0 & 0.9429 & 0.1527 & 5.5 \\
\hline
\end{tabular}

Values followed by different letters in the same line differ by lsmeans procedure at $10 \%$ of significance. *Probability of feeding systems; **Probability of interaction feeding systems $\times$ grazing cycles; $* * * \mathrm{SD}=$ average standard deviation; ${ }^{1}$ Feeding systems: Alexandergrass $=$ heifers exclusively on Alexandergrass; $\mathrm{Al}+0.5=$ heifers on Alexandergrass and receiving $0.5 \%$ of body weight $(\mathrm{BW})$ of rice bran $(\mathrm{RB}) ; \mathrm{Al}+1.0=$ heifers on Alexandergrass and receiving $1.0 \%$ of $\mathrm{BW}$ of $\mathrm{RB} ;{ }^{2} \mathrm{~cm} ;{ }^{3} \mathrm{~kg} \mathrm{ha}{ }^{-1}$ of DM; ${ }^{4} \mathrm{~kg}$ of DM $100 \mathrm{~kg}^{-1}$ of BW; ${ }^{5} \%$

Heifers in different feeding systems grazed in paddocks with similar $(\mathrm{P}>0.05)$ average forage mass $\left(3,884 \mathrm{~kg}\right.$ DM ha $\left.{ }^{-1}\right)$, leaf blade mass (894.6kg DM ha $\left.{ }^{-1}\right)$, stem mass (1996.2kg DM ha $\left.{ }^{1}\right)$, leaf: stem ratio $(0.5)$, forage allowance $(8.3 \mathrm{~kg}$ DM $100 \mathrm{~kg} \mathrm{BW}^{-1}$ ) and leaf blade allowance $\left(2.0 \mathrm{~kg}\right.$ DM $\left.100 \mathrm{~kg} \mathrm{BW}^{-1}\right)$. These values indicate that the sward conditions were similar in all 
paddocks used to evaluate feeding systems. The forage allowance observed when heifers were kept exclusively on pasture $(9.2 \mathrm{~kg}$ DM $100 \mathrm{~kg}$ $\mathrm{BW}^{-1}$ ) was close to the value of $10-12 \%$ suitable for tropical pastures (Sollenberger and Burns, 2001).

We observed no interaction $(\mathrm{P}>0.05)$ between feeding systems $\times$ grazing cycles for in situ DM digestibility, crude protein, neutral detergent fiber and total digestible nutrients of forage from forage as grazed (Table 1). In different feeding systems, heifers consumed forage with similar $(\mathrm{P}>0.05)$ in situ DM digestibility (DISDM; $66.4 \%$ ) and total digestible nutrients (TDN; $62.3 \%)$.

The content of neutral detergent fiber (NDF) of forage as grazed when heifers were kept exclusively on pasture was $5.3 \%$ higher when compared to the forage consumed by heifers that received $1.0 \% \mathrm{BW}$ of $\mathrm{RB}$ (Table 1). In the feeding system in which heifers received $0.5 \%$ $\mathrm{BW}$ of RB, this value was similar to the others. This suggests that the supplemented animals have been more selective during grazing, seeking areas with a higher proportion of leaf blades. This structural component of forage plants has lower NDF content (Van Soest, 1994), while in stems, this value is higher. This is consistent with the assertion that supplemented animals show greater selectivity, thereby increasing the efficiency in taking nutrients from the forage (Krysl and Hess, 1993). Because of this increased selectivity of animals receiving supplement, it was observed that the heifers that received $1.0 \% \mathrm{BW}$ of $\mathrm{RB}$ consumed forage with crude protein content $9.7 \%$ higher than heifers in the others feeding systems (Table 1).

The in-situ DM digestibility of forage as grazed in different feeding systems averaged $66.4 \%$. In tropical grasses, digestibility values rarely exceed $70 \%$ (Van Soest, 1994). This value was $14.6 \%$ higher than the observed $(57.9 \%)$ in Alexandergrass under continuously stocking with heifers supplemented with oat grain (Sichonanyet al., 2015).

We observed no interaction between feeding systems $\times$ grazing cycles for variables related to DM intake (Table 2). When supplement was given, there was a positive association between forage and supplement, which resulted in additive effects of supplement intake on total dry matter intake. The provision of supplement, regardless of the level, promoted a $21.1 \%$ higher $(\mathrm{P}<0.05)$ total dry matter intake $(3.15 \% \mathrm{BW})$ when compared with the exclusive use of pasture $(2.6 \% \mathrm{BW})$, which was similar to the estimated value $(2.7 \% \mathrm{BW})$ for heifers with average body weight of $318 \mathrm{~kg}$ and average daily gain of $800 \mathrm{~g}$ (NRC, 1996).

The addition rate observed in the feeding systems which RB was utilized, independent of its level, was 0.85 , that is, for each $\mathrm{kg}$ of supplement consumed, there was an increase of $0.85 \mathrm{~kg}$ in the total DM intake. This increase can be explained by the shorter retention time of digesta in the rumen, when the animals receive supplement, due to increased frequency of rumen contractions and passage rate of digesta (Okineet al., 1989).

Higher total DM intake enabled the supplemented heifers to receive higher amount of CP (0.41\% BW; Table 2) and TDN (2.0\% BW). These values were, respectively, 26 and $25 \%$ higher compared to heifers exclusively on pasture (Table 2). Exclusively on Alexandergrass, heifers consumed amount of $\mathrm{CP}$ $(0.33 \% \mathrm{BW}) 37 \%$ higher to that required $(0.24 \%$ BW) by heifers with average body weight of $318 \mathrm{~kg}$ and $800 \mathrm{~g}$ of ADG (Nutrient..., 1996). Heifers consumed $1.6 \%$ of TDN with enabled ADG $16 \%$ lower than that provided by RB, when supplied at a level of $0.5 \% \mathrm{BW}$ (Table 3), indicating that ADG was determined by the availability of energy in the diet and not by protein content. 
Table 2. Dry matter intake of forage, total dry matter intake, crude protein intake of forage, total crude protein intake, total nutrients digestible intake and neutral detergent fiber intake by heifers on different feeding systems

\begin{tabular}{|c|c|c|c|c|c|c|}
\hline \multirow[b]{2}{*}{ Feeding systems $^{1}$} & \multicolumn{2}{|c|}{ Grazings cycles } & \multirow[b]{2}{*}{ Average } & \multirow[b]{2}{*}{$\mathrm{P}^{*}$} & \multirow[b]{2}{*}{$\mathrm{P} * *$} & \multirow[b]{2}{*}{$\mathrm{SD} * * *$} \\
\hline & $\begin{array}{c}02 / 22- \\
03 / 10 / 15\end{array}$ & $\begin{array}{c}03 / 26- \\
04 / 19 / 15\end{array}$ & & & & \\
\hline \multicolumn{7}{|c|}{ Dry matter intake of forage ${ }^{2}$} \\
\hline Alexandergrass & 2.9 & 2.3 & $2.6^{\mathrm{a}}$ & & & \\
\hline Alexandergrass $+0.5 \% \mathrm{RB}$ & 2.9 & 2.5 & $2.7^{\mathrm{a}}$ & 0.0189 & 0.1065 & 0.39 \\
\hline Alexandergrass $+1.0 \% \mathrm{RB}$ & 2.2 & 2.3 & $2.2^{\mathrm{b}}$ & & & \\
\hline Average & 2.7 & 2.4 & & 0.0425 & & \\
\hline \multicolumn{7}{|c|}{ Total dry matter intake ${ }^{2}$} \\
\hline Alexandergrass & 2.9 & 2.3 & $2.6^{\mathrm{b}}$ & & & \\
\hline Alexandergrass $+0.5 \% \mathrm{RB}$ & 3.4 & 3.0 & $3.2^{\mathrm{a}}$ & 0.0085 & 0.1161 & 0.40 \\
\hline Alexandergrass $+1.0 \% \mathrm{RB}$ & 3.0 & 3.2 & $3.1^{\mathrm{a}}$ & & & \\
\hline Average & 3.1 & 2.8 & & 0.0527 & & \\
\hline \multicolumn{7}{|c|}{ Crude protein intake of forage ${ }^{2}$} \\
\hline Alexandergrass & 0.43 & 0.24 & 0.33 & & & \\
\hline Alexandergrass $+0.5 \% \mathrm{RB}$ & 0.43 & 0.26 & 0.35 & 0.1806 & 0.1017 & 0.09 \\
\hline Alexandergrass $+1.0 \% \mathrm{RB}$ & 0.33 & 0.26 & 0.29 & & & \\
\hline Average & 0.39 & 0.25 & & $<0.0001$ & & \\
\hline \multicolumn{7}{|c|}{ Total crude protein intake ${ }^{2}$} \\
\hline Alexandergrass & 0.43 & 0.24 & $0.33^{\mathrm{b}}$ & & & \\
\hline Alexandergrass $+0.5 \% \mathrm{RB}$ & 0.49 & 0.33 & $0.41^{\mathrm{a}}$ & 0.0162 & 0.1246 & 0.09 \\
\hline Alexandergrass $+1.0 \% \mathrm{RB}$ & 0.46 & 0.39 & $0.42^{\mathrm{a}}$ & & & \\
\hline Average & 0.46 & 0.32 & & $<0.0001$ & & \\
\hline \multicolumn{7}{|c|}{ Total digestible nutrients intake ${ }^{2}$} \\
\hline Alexandergrass & 2.0 & 1.3 & $1.6^{\mathrm{b}}$ & & & \\
\hline Alexandergrass $+0.5 \% \mathrm{RB}$ & 2.2 & 1.8 & $2.0^{\mathrm{a}}$ & 0.0259 & 0.0563 & 0.35 \\
\hline Alexandergrass $+1.0 \% \mathrm{RB}$ & 2.1 & 1.9 & $2.0^{\mathrm{a}}$ & & & \\
\hline Average & 2.1 & 1.7 & & 0.0018 & & \\
\hline \multicolumn{7}{|c|}{ Neutral detergent fiber intake ${ }^{2}$} \\
\hline Alexandergrass & 1.8 & 1.5 & $1.7^{\mathrm{ab}}$ & & & \\
\hline Alexandergrass $+0.5 \% \mathrm{RB}$ & 1.9 & 1.7 & $1.8^{\mathrm{a}}$ & 0.0711 & 0.0606 & 0.20 \\
\hline Alexandergrass $+1.0 \% \mathrm{RB}$ & 1.5 & 1.6 & $1.6^{\mathrm{b}}$ & & & \\
\hline Average & 1.7 & 1.6 & & 0.1217 & & \\
\hline
\end{tabular}

Values followed by different letters in the same column differ by lsmeans procedure at $10 \%$ of significance. *Probability of feeding systems; **Probability interaction feeding systems $\times$ grazing cycles; ***SD= average standard deviation; ${ }^{1}$ Feeding systems: Alexandergrass $=$ heifers exclusively on Alexandergrass; Alexandergrass $+0.5 \% \mathrm{RB}=$ heifers on Alexandergrass fed $0.5 \%$ body weight of rice bran; Alexandergrass $+1.0 \% \mathrm{RB}=$ heifers on Alexandergrass fed $0.5 \%$ body weight of rice bran; ${ }^{2} \%$ of body weight. 
Table 3. Productive parameters of heifers on different feeding systems

\begin{tabular}{llllll}
\hline \multirow{2}{*}{ Parameters } & \multicolumn{2}{l}{ Feeding systems $^{1}$} & \multicolumn{2}{c}{ P $^{* *}$} & SD $^{*}$ \\
\cline { 2 - 5 } & Alexandergrass & Al+0.5 & Al+1.0 & & \\
\hline Average daily gain $^{2}$ & $0.865^{\mathrm{b}}$ & $1.025^{\mathrm{a}}$ & $0.991^{\mathrm{ab}}$ & 0.0645 & 0.14 \\
Body weight gain per area $^{3}$ & $495^{\mathrm{b}}$ & $588^{\mathrm{ab}}$ & $629^{\mathrm{a}}$ & 0.0927 & 74.7 \\
Stocking rate $^{3}$ & $2462.1^{\mathrm{b}}$ & $2628.2^{\mathrm{ab}}$ & $2925.8^{\mathrm{a}}$ & 0.0347 & 358.0 \\
Hip height gain $^{4}$ & $4.7^{\mathrm{b}}$ & $6.2^{\mathrm{a}}$ & $7.0^{\mathrm{a}}$ & 0.0360 & 0.96 \\
Final body condition score $^{\mathrm{a}}$ & $3.8^{\mathrm{a}}$ & $3.8^{\mathrm{a}}$ & $3.9^{\mathrm{a}}$ & 0.6864 & 0.16 \\
Final body weight $^{5}$ & $341.2^{\mathrm{b}}$ & $348.7^{\mathrm{ab}}$ & $366.2^{\mathrm{a}}$ & 0.0707 & 22.5 \\
\hline
\end{tabular}

Values followed by different letters in the same line differ by lsmeans procedure at $10 \%$ of significance. *Probability of feeding systems; **SD = average standard deviation; ${ }^{1}$ Feeding systems: Alexandergrass $=$ heifers exclusively on Alexandergrass; $\mathrm{Al}+0.5=$ heifers on Alexandergrass and receiving $0.5 \%$ of body weight $(\mathrm{BW})$ of rice bran $(\mathrm{RB})$; $\mathrm{Al}+1.0=$ heifers on Alexandergrass and receiving $1.0 \%$ of BW of $\mathrm{RB} ;{ }^{2} \mathrm{~kg}$ day ${ }^{-1} ;{ }^{3} \mathrm{~kg} \mathrm{ha}{ }^{-1}$ of BW; ${ }^{4} \mathrm{~cm} ;{ }^{5} \mathrm{~kg}$

Heifers receiving $1.0 \% \mathrm{BW}$ of $\mathrm{RB}$ presented ADG similar to the gain achieved by heifers in the others feeding systems. This result, at this level of supplementation, can be partially related to the fat content provided by RB (4.6\% DM). This content has exceeded the level of $3 \%$ of the total DM consumed, below which, it would be obtained the greatest benefit from the fat energy, when the basal diet consists of forage (Hess et al., 2008). The intake of high fat levels can affect rumen fermentation and fiber digestibility by forming a fatty layer around the fiber particles, hindering the action of cellulolytic bacteria in the rumen (Palmquist and Jenkins, 1980; Hess et al., 2008). When provided $0.5 \% \mathrm{BW}$ of $\mathrm{RB}$ for heifers, the percentage fat content was $2.3 \% \mathrm{DM}$, value $23 \%$ lower than the maximum limit recommended by the same authors.

In the feeding system in which heifers were supplemented with $1 \% \mathrm{BW}$ of $\mathrm{RB}$, we observed lower forage DM intake (Table 2) than in the others feeding systems, which were similar to each other. This can be related to the amount of fat ingested by heifers being superior to the maximum value indicated by Hess et al. (2008). In this feeding system, the substitution coefficient was 0.40 , in other words, for each $\mathrm{kg}$ of supplement consumed, $0.40 \mathrm{~kg}$ DM forage was not consumed. The substitution coefficient caused by RB utilization was higher than the value of 0.27 observed by the supply of corn grain, a supplement rich in starch, to heifers in ryegrass pasture (Rosa et al., 2013), whereas the main source of energy of RB derives from fat (White and Hembry, 1985).
In the feeding system which heifers received $0.5 \% \mathrm{BW}$ of RB, we observed a total NDF intake $12.5 \%$ higher than heifers receiving $1.0 \% \mathrm{BW}$ of RB (Table 2). When heifers were kept exclusively on pasture, total NDF intake was similar to other feeding systems.

Regardless of the considered feeding system, heifers showed total NDF intake (Table 2) similar to the value observed by Barbosa et al. (2007) and Oliveira et al. (2013), which found, in tropical pastures, NDF intake of 1.8 and $1.7 \%$ $\mathrm{BW}$, respectively. These results are superior to the value of $1.2 \% \mathrm{BW}$, reported by Mertens (1994). This corroborates Silva et al.'s (2009) affirmative that, in tropical pastures, higher values of NDF intake may be associated with control of the total dry matter intake.

In the feeding system in which the heifers received $1.0 \% \mathrm{BW}$ of $\mathrm{RB}$, body weight gain per area (BWA) was $27 \%$ higher than in heifers maintained exclusively grazing (Table 2), as a reflex from individual weight gain and the greater stocking rate observed. The BWA in the feeding system in which heifers received $0.5 \%$ BW of RB was similar to other feeding systems. Even when the ultimate goal of the livestock system is not the slaughter of animals, weight gain per area is the decision-making component in determining the income. In addition, greater weight gain per area in a system whose goal is to reduce the age at first mating may indicate greater efficiency in the use of pastures and/or a way to have more heifers with adequate weight at the first mating (Potter et al., 2010). 
At the end of the experimental period, heifers that received $1.0 \% \mathrm{BW}$ of $\mathrm{RB}$ showed $7.3 \%$ higher body weight than heifers exclusively on Alexandergrass pasture (Table 2). The final body weight of heifers that received $0.5 \% \mathrm{BW}$ of $\mathrm{RB}$ was similar to other feeding systems.

The hip height gain (HHG) was $40 \%$ higher in feeding systems in which the heifers were supplemented with RB, independent of its level (Table 3) and can be explained by increased bone growth due to the higher nutrient availability when animals are supplemented (Rezende et al., 2011). When the animals have greater height, it is usually observed a delay in the inflection of their growth curve, slowing the early accumulation of body fat (Nise and Brink, 1985). It may have been responsible for similar body condition score (BCS) in the different feeding systems at the end of the pasture utilization (3.8 points; Table 3). The heifers exhibited higher BCS, regardless of the feeding system evaluated, than the minimum value indicated by Rocha and Lobato (2002) to express puberty and be mated.

\section{CONCLUSION}

The use of whole rice bran up to $1 \%$ body weight (BW) causes no change in the total dry matter (DM) intake, average daily gain, stocking rate and BW gain per area compared to the supply of $0.5 \% \mathrm{BW}$ rice bran. Heifers exclusively on Alexandergrass pasture consumed a lower total amount of DM.In Alexandergrass pasture, under rotational stocking, supply of $0.5 \% \mathrm{BW}$ whole rice bran for beef heifers from 15 to 18 months of age is recommended, for promoting better productive responses compared to heifers exclusively on pasture and similar to those observed when $1.0 \% \mathrm{BW}$ whole rice bran is given.

\section{REFERENCES}

BARBOSA, F.A.; GRAÇA, D.S.; MAFFEI, W.E. et al. Desempenho e consumo de matéria seca de bovinos sob suplementação protéico-energética, durante a época de transição água-seca. Arq.Bras. Med. Vet. Zootec., v.59, p.160-167, 2007.

BLIGH, E.G.; DYER, W.A rapid method of total lipid extraction and purification.Can. J. Biochem. Physiol.,v.37, p.911-917, 1959.
CONSULTA de dados da estação automática. Santa Maria: INMET. www.inmet.gov.br. Acessado em: 04 abril, 2015.

COSTA, V.G.; ROCHA, M.G.; PÖTTER, L. et al. Comportamento de pastejo e ingestão de forragem por novilhas de corte em pastagens de milheto e papuã. Rev. Bras. Zootec., v.40, p.251-259, 2011.

DEMARQUILLY, C.; CHENOST, M.; AUBRY, J. et al. Etude de la digestion des fourrages dans le rumen par la méthods des sachets de nylon; liaisons avec la valeur alimentaire. Ann. Zootec., v.18, p.419-430, 1969.

ELOY, L.R.; ROCHA, M.G.; PÖTTER, L. et al. Biomass flows and defoliation patterns of alexandergrass pasture grazed by beef heifers, receiving or not protein salt. Acta Sci., Anim. Sci., v.36, p.123-128, 2014.

EUCLIDES, V.P.B.; MACEDO, M.C.M.; OLIVEIRA, M.P. Avaliação de diferentes métodos de amostragem para estimar o valor nutritivo de forragens sob pastejo. Rev. Bras. Zootec., v.29, p.2200-2208, 1992.

GRÃOS - Séries históricas. CONAB - Companhia Nacional de Abastecimento. Disponível em: <http//www.conab.gov.br>. Acessado em: 05 set, 2015.

HESS, B.W.; MOSS, G.E.; RULE, D.C.A decade of developments in the area of fat supplementation research with beef cattle and sheep.J. Anim. Sci., v.86, p.188-204, 2008.

HODGSON, J. Grazing management: science into practice. England: Longman Scientific \& Technical, 1990. 203p.

KOZLOSKI, G.V.; FLORES, E.M.M.; MARTINS, A.F. Use of chromium oxide in digestibility studies: variations of the results as a function of the measurement method. J. Sci. Food Agric., v.76, p.373376, 1998.

KOZLOSKI, G.V.; PEREZ NETTO, D.; OLIVEIRA, L. et al. Uso de óxido de cromo como indicador da excreção fecal de bovinos em pastejo: variação das estimativas em função do horário de amostragem. Cienc.Rural, v.36, p.599-603, 2006.

KRYSL, L.J.; HESS, B.W. Influence of supplementation on behavior of grazing cattle.J. Anim. Sci., v.71, p.2546-2555, 1993.

KUNKLE, W.E.; BATES, D.B. Evaluating feed purchasing options: energy, protein, and mineral supplements. In: FLORIDA BEEF CATTLE SHORT COURSE, 1998, Gainesville. Proceedings... Gainesville: University of Florida, 1998. p.59-70. 
LANÇANOVA, J.A.C.; RESTLE, J.; SANTOS, G.L. Produção e qualidade do capim papuã (Brachiariaplantaginea) sob efeito de frequências de corte e nitrogênio. Cienc.Rural, v.18, p.343-354, 1988.

LOWMAN, B.G.; SCOTT, N.; SOMERVILLE, S. Condition scoring beef cattle. Edinburgh: East of Scotland College of Agriculture, 1973. 8p. (Bulletin $6)$.

MERTENS, D.R. Regulation of forage intake. In: FAHEY JR., G.C. (Ed.). FORAGE QUALITY EVALUATION AND UTILIZATION, 1994, Madison. Proceedings... Madison: American Society of Agronomy/Crop Science of America/Soil Science of America, 1994. p.450-493.

NISE, R.S.K.; BRINKS, J.S. Genetic and environmental aspects of the growth curve parameters in beef cows.J. Anim. Sci., v.61, p.1431-1443, 1985.

NUTRIENT requirements of beef cattle.7.ed. Washington D.C.: National Academy Press, 1996. 248p.

NUTRIENT requirements of dairy cattle.7.ed. rev. Washington, D.C.: National Academy Press, 2001. $408 \mathrm{p}$.

OFFICIAL methods of analysis.16.ed. Gaithersburg: AOAC, 1997. (Method 984.13).

OKINE, E.K.; MATHISON, G.W.; HARDIN, R.T. Effects of changes in frequency of reticular constractions on fluid and particulate passage rates in cattle.J. Anim. Sci., v.67, p.3388-3396, 1989.

OLIVEIRA NETO, R.A.; SILVA, J.H.S.; ROCHA, M.G. et al. Ingestivebehaviour, performance and forage intake by beef heifers on tropical pasture systems. Rev. Bras. Zootec., v.42, p.549-558, 2013.

PALMQUIST, D.L.; JENKIS, T.C. Fat in lactation rations: review. J. Anim. Sci., v.63, p.1-14, 1980.

POND, K.R.; ELLIS, W.C.; MATIS, J.H. et al. Passage of chromium-mordanted and rare earthlabeled fiber: time of dosing kinetics. J. Anim. Sci., v.67, p.1020-1028, 1989.

PÖTTER, L.; ROCHA, M.G.; ROSO, D. et al. Suplementação com concentrado para novilhas de corte mantidas em pastagens cultivadas de estação fria. Rev. Bras. Zootec., v.39, p.992-1001, 2010.

REZENDE, P.L.; RESTLE, J.; FERNADES, J.J.R. et al. Desempenho e desenvolvimento corporal de bovinos leiteiros mestiços submetidos a níveis de suplementação em pastagem de Brachiariabrizantha. Cienc. Rural, v.41, p.1453-1458, 2011.
ROCHA, M.G.; LOBATO, J.F.P. Sistemas de alimentação pós-desmama de novilhas de corte para acasalamento com 14/15 meses de idade. Rev. Bras. Zootec., v.31, p.1814-1822, 2002.

ROSA, A.T.N.; ROCHA, M.G.; PÖTTER, L. et al.Consumo de forragem e desempenho de novilhas de corte recebendo suplementos em pastagem de azevém. Cienc. Rural, v.43, p.126-131, 2013.

SALVADOR, P.R.; PÖTTER, L.; ROCHA, M.G. et al. Fluxos de tecidos foliares em papuã sob pastejo de bezerras de corte em diferentes frequências de suplementação. Rev. Bras. Saúde Prod. Anim., v.15, p.835-845, 2014.

SENGER, C.D.; KOSLOSKY, G.V.; SANCHES, L.M.B. et al. Evaluation of autoclave procedures for fibreanalisys in forage and concentrate feedstuffs. Anim. Feed Sci. Technol., v.146, p.169-174, 2008.

SICHONANY, M.J.O.; ROCHA, M.G.; PÖTTER L. et al.Ingestive behavior of heifers in Alexandergrass pasture receivingdifferent amounts of oat grain as supplement. Semin.Ciênc.Agrár., v.36, p.2763-2774, 2015.

SILVA, F.F.; SÁ, J.F.; SCHIO, A.R. et al. Suplementação a pasto: disponibilidade e qualidade $\mathrm{x}$ níveis de suplementação x desempenho. Rev. Bras. Zootec., v.38, p.371-389, 2009.

SISTEMA brasileiro de classificação de solos. Brasília: Embrapa-SPI; Rio de Janeiro: EmbrapaSolos, 2006. 306p.

SOLLENBERGER, L.E.; BURNS, J.C. Canopy characteristics, ingestive behavior and herbage intake in cultivated tropical grasslands.In: INTERNATIONAL GRASSLAND CONGRESS, 2001, São Pedro. Proceedings... São Pedro: São Paulo, 2001. v.19.

SOUZA, A.N.; ROCHA, M.; ROSO, D.et al.Productivity and reproductive performance of grazing beef heifers bread at 18 month of age. Rev. Bras. Zootec., v.41, p.306-313, 2011.

STATISTICAL analysis system.Version 9.4. Cary: SAS Institute, 2009.

VAN SOEST, P.J. Nutritional ecology of the ruminant. 2.ed. Ithaca: Cornell University Press, 1994. $476 \mathrm{p}$.

WHITE, T.W.; HEMBRY, F.G. Rice by-products in ruminants rations. La. Agric. Exp. Stn.Bull., n.771, $18 \mathrm{p}, 1985$. 